\title{
Preparation and Characterization of Ni-Doped Calcium Silicate Hydrate Based on Steel Slag: Adsorption Capacity for Rhodamine B from Aqueous Solution
}

\author{
Lu Zeng and Ligang Yang \\ College of Materials Science and Engineering, Chongqing University, Chongqing 400044, China \\ Correspondence should be addressed to Lu Zeng; zenglu@cqu.edu.cn
}

Received 17 February 2015; Revised 30 April 2015; Accepted 4 May 2015

Academic Editor: Kaustubha Mohanty

Copyright (C) 2015 L. Zeng and L. Yang. This is an open access article distributed under the Creative Commons Attribution License, which permits unrestricted use, distribution, and reproduction in any medium, provided the original work is properly cited.

Calcium silicate hydrate based on steel slag (SCSH) and Ni-doped SCSH (NSCSH) were synthesized under specific hydrothermal conditions at saturated vapor pressure and $185^{\circ} \mathrm{C}$ for 7 hours. The structure and morphology of SCSH and NSCSH were characterized by XRD, SEM, and $\mathrm{N}_{2}$ adsorption/desorption. SCSH mainly consisted of amorphous calcium silicate hydrate gel (C-S-H gel) together with some flake-like tobermorite and NSCSH consisted of crystalline tobermorite and xonotlite. The addition of $\mathrm{Ni}\left(\mathrm{NO}_{3}\right)_{2}$ had great influence on microstructure of the composites, and SCSH possesses a mesoporous structure with slit-shaped pores, but NSCSH has narrow distributions of pore size. Furthermore, NSCSH has a higher adsorption capacity for Rhodamine B $(\mathrm{RhB})$ than SCSH with removal percentages of RhB of about $52.4 \%$ and $88.2 \%$, respectively. In addition, the effects of NSCSH dosage and $\mathrm{pH}$ values on the adsorption of $\mathrm{RhB}$ were investigated. Adsorption isotherm parameters are obtained from both Langmuir and Freundlich analysis and showed a better fit to a Langmuir model. All results indicated that NSCSH has a great potential to be a safe, easily-made, and cost-effective material for the control of $\mathrm{RhB}$ contamination.

\section{Introduction}

The synthesis of calcium silicate hydrates (CSHs) in the hyperalkaline and hydrothermal environments has been extensively studied. Under different hydrothermal conditions, varieties of CSHs with different structures can be prepared, such as $11 \AA$ tobermorite $\left(\mathrm{Ca}_{5} \mathrm{Si}_{6} \mathrm{O}_{16}(\mathrm{OH})_{2} \cdot 4 \mathrm{H}_{2} \mathrm{O}\right)$ and xonotlite $\left(\mathrm{Ca}_{6} \mathrm{Si}_{6} \mathrm{O}_{17}(\mathrm{OH})_{2}\right)$ which usually occur in nature as hydrothermal alteration products in contact zones of $\mathrm{Ca}$ bearing rocks, with the basic igneous ones [1-5]. The structures of $11 \AA$ tobermorite and xonotlite are built up of sheets of six and seven coordinated Ca polyhedra, which are ribbed on both sides by wollastonite-type silicate chains $[6,7]$. Moreover, the structure of $11 \AA$ tobermorite consists of a central layer of calcium octahedra which has silicate sheets on each side [8], and it can be described as "normal" or "anomalous" depending on its shrinkage behavior on heating [9]. The structure of xonotlite is very similar to tobermorite, but it has double chains parallel to the $b$-axis which forms layers in the $a b$ plane rather than the single chains in tobermorite [10].
Nowadays, calcium silicate hydrates are generally used as functional materials, especially as an adsorbent due to their high specific surface area and a large number of structural sites within the porous structure. Many studies have been devoted to the removal capacity of natural and synthetic crystalline CSHs for heavy metal ions. Thus, the uptake of by CSHs has been reported [11-16]. Moreover, in the study of Chen et al. [5], xonotlite was synthesized and served as a seed crystal for the removal and recovery of phosphate from aqueous solution. In addition, the phosphate removal capacity of xonotlite was investigated depending on different dosages and $\mathrm{pH}$ values. Katsumata et al. [17] removed natural organic polyelectrolyte (humic and fulvic acids) and their metal complexes by adsorption onto xonotlite. Thus, xonotlite plays a role in fixing heavy metals by ion-exchange and adsorption due to its similarity with tobermorite $[14,15]$.

Steel slag is a common by-product from iron and steel production and is little used, and its composites and mineral phases are similar to those of cement. As a result, it is available for preparing calcium silicate hydrate via hydrothermal reaction from steel slag [18]. However, it has been reused as a 
TABLE 1: Adsorption capacity of RhB onto natural materials.

\begin{tabular}{|c|c|c|c|c|c|c|c|}
\hline Adsorbent & Titania-silica & Zeolite MCM-22 & Red mud & $\begin{array}{c}\text { Australian natural } \\
\text { zeolite }\end{array}$ & $\begin{array}{l}\text { Coal } \\
\text { ash }\end{array}$ & $\begin{array}{c}\text { Orange } \\
\text { peel }\end{array}$ & $\begin{array}{c}\text { Banana } \\
\text { peel }\end{array}$ \\
\hline $\begin{array}{l}\text { Adsorption capacity } \\
\left(\mathrm{mg} \cdot \mathrm{g}^{-1}\right)\end{array}$ & 0.11 & 1.11 & 1.44 & 2.12 & 2.86 & 4.82 & 8.63 \\
\hline
\end{tabular}

coarse aggregate for concrete and raw material for cement, but the utilization is low [19]. Hence, it is practical and meaningful to explore some new applications for steel slag with high utilization. Currently, steel slag has been studied as an adsorbing material, such as the removal of phosphate, ammonium ions, dissolved organic pollutant, and several hazardous ions from aqueous solution [20-24]. Asaoka et al. [25] revealed the removal mechanism of hydrogen sulfide in the pore water of eutrophic sediments by using carbonated steel slag which was produced through carbonation processes to alleviate alkaline impacts.

Up till now, there have been few reports about the hydrothermal synthesis of calcium silicate hydrates using steel slag (SCSH) for the adsorption of contaminant. In this study, in order to accelerate the formation of more crystalline CSHs, small amounts of $\mathrm{Ni}\left(\mathrm{NO}_{3}\right)_{2}$ were introduced since it could affect the final product of calcium silicate hydrate (NSCSH). NSCSH has been used to bind hazardous dye from aqueous solution. The dye under consideration is Rhodamine $\mathrm{B}(\mathrm{RhB})$, which is widely used as a colorant in textiles [26]; it can cause irritation to the skin, eyes, and respiratory tract and has been found to be carcinogenic for human beings and animals [27]. Nowadays, different kinds of adsorbents have been investigated for the removal of Rhodamin B as shown in Table 1 [28-33]. The novelty of this research is that steel slag used to prepare CSHs can improve its utilization rate on one hand and the introduction of $\mathrm{Ni}^{2+}$ on the other can enhance the adsorption capacity of CSHs, as compared with the common adsorbents presented in Table 1. Samples were analyzed by several methods, such as XRD, SEM, and $\mathrm{N}_{2}$ adsorption/desorption. Moreover, the adsorption capacities of SCSH and NSCSH for the removal of RhB from aqueous solution were investigated and the adsorption mechanism of RhB on NSCSH was explained.

\section{Materials and Methods}

2.1. Materials. The steel slag (Laiwu Steel Co., Ltd.) with a specific surface area of $190 \mathrm{~m}^{2} \mathrm{~kg}^{-1}$ and an average particle size of $8.83 \mu \mathrm{m}$ was obtained after ball-milling for $1 \mathrm{~h}$. The main chemical components are shown in Table 2. Calcium oxide $(99.99 \% \mathrm{CaO})$, silicon oxide $\left(99.99 \% \mathrm{SiO}_{2}\right)$, Rhodamine $\mathrm{B}(\mathrm{RhB})$, and $\mathrm{Ni}\left(\mathrm{NO}_{3}\right)_{2}(\mathrm{AR}, 98 \%)$ were purchased from Aladdin Chemistry Co., Ltd. All other chemicals used in this study such as $\mathrm{HCl}, \mathrm{NH}_{4} \mathrm{Ac}$, which were used as analytical reagents, were supplied by Xige Laboratory equipment Co., Ltd.

2.2. Preparation of Calcium Silicate Hydrate Using Steel Slag. SCSH was synthesized in an autoclave (Weihai Chemical Machinery Co., Ltd.) by hydrothermal synthesis. The total
TABLE 2: Chemical components of samples.

\begin{tabular}{lccccccc}
\hline wt\% & $\mathrm{CaO}$ & $\mathrm{SiO}_{2}$ & $\mathrm{MgO}$ & $\mathrm{Al}_{2} \mathrm{O}_{3}$ & $\mathrm{Fe}_{2} \mathrm{O}_{3}$ & $\mathrm{P}_{2} \mathrm{O}_{5}$ & $\begin{array}{c}\text { Loss on } \\
\text { ignition }\end{array}$ \\
\hline Steel slag & 45.8 & 16.8 & 6.6 & 3.1 & 22.7 & 1.7 & 3.3 \\
\hline
\end{tabular}

mass of starting materials was $100 \mathrm{~g}$, which were mixed in the mass ratio of steel slag/calcium oxide/silicon oxide $=$ $1: 0.05: 0.38$ to provide starting samples with $\mathrm{Ca} / \mathrm{Si}=1$. The mixture was added to the water in the mass ratio of $w / s=10: 1$ and then put into a mixer and sufficiently mixed for $30 \mathrm{~min}$. Subsequently, the mixtures were incubated at $185^{\circ} \mathrm{C}$ for 7 hours to manufacture SCSH. After being created, the sample was dried to constant mass in an oven (Chengdu Shengjie Technology Co., Ltd.) at $105^{\circ} \mathrm{C}$ and then milled to less than $45 \mu \mathrm{m}$ for the adsorption experiments. The same method was used to synthesize the NSCSH, and the mass ratio of steel slag/calcium oxide/silicon oxide and $w / s$ remained unchanged; the only difference was the addition of another 5 percent of $\mathrm{Ni}\left(\mathrm{NO}_{3}\right)_{2}$. The hydrothermal synthesis conditions and quantity of initial reactants of SCSH and NSCSH are shown in Table 3.

2.3. Characterization of Specimens. X-ray diffraction (XRD) patterns of specimens were measured on a Rigaku D/max1200 diffractometer equipped with a rotating anode and $\mathrm{CuK} \alpha$ irradiation, in the range of $5-70^{\circ} 2 \theta$ and a a step size of $0.02^{\circ}$. SEM micrographs were performed by using a TESCAN VEGA 3 scanning electron microscope, operating at the accelerating voltage of $20 \mathrm{kV}$ and taking images at different magnifications. Brunauer-Emmett-Teller (BET) specific surface area, total pore volumes, and average pore diameter of the samples were measured from $\mathrm{N}_{2}$ adsorption/desorption isotherms at $77 \mathrm{~K}$, using automatic specific surface area measuring equipment (ASAP, 2020, Micromeritics, USA) after degassing under vacuum for $8 \mathrm{~h}$ at $383 \mathrm{~K}$.

2.4. Adsorption Experiments. Firstly, RhB stock solution (500 $\mathrm{mg} \mathrm{L}^{-1}$ ) was prepared, and in order to prepare $10 \mathrm{mg}$ $\mathrm{L}^{-1}$ solution, the stock solution was diluted to $100 \mathrm{~mL}$ with distilled water. The CSH specimen $(100 \mathrm{mg})$ was added to $100 \mathrm{~mL}$ aqueous solution of RhB dye and placed in a $150 \mathrm{~mL}$ Erlenmeyer flask. The solution was magnetically stirred and was subsequently centrifuged at the time points of 2, 5, 10, 20, 30 , and $60 \mathrm{~min}$. The absorbance of the supernatant solution was measured on a UV-vis spectrophotometer (Beijing Puxi General Instrument Co., Ltd.) at the maximum absorption wavelength of $554 \mathrm{~nm}$. The adsorption rate was calculated by (A.1), where $\eta$ is the adsorption ratio of $\mathrm{RhB}$ and $A_{C 0}$ and $A_{C t}$, 
TABle 3: Parameters for hydrothermal synthesis of calcium silicate hydrate from steel slag.

\begin{tabular}{|c|c|c|c|c|c|c|c|c|}
\hline Samples & $\mathrm{Ca} / \mathrm{Si}$ & $w / s$ & $\begin{array}{l}\text { Incubating time } \\
\text { (h) }\end{array}$ & $\begin{array}{c}\text { Temperature } \\
\left({ }^{\circ} \mathrm{C}\right)\end{array}$ & $\begin{array}{l}\mathrm{CaO} \\
(\mathrm{g})\end{array}$ & $\begin{array}{l}\mathrm{SiO}_{2} \\
(\mathrm{~g})\end{array}$ & $\begin{array}{c}\text { Steel slag } \\
(\mathrm{g})\end{array}$ & $\begin{array}{l}\mathrm{Ni}\left(\mathrm{NO}_{3}\right)_{2} \\
(\mathrm{~g})\end{array}$ \\
\hline$\overline{\mathrm{SCSH}}$ & 1.0 & 10 & 7 & 185 & 3.69 & 26.31 & 70 & 0 \\
\hline $\mathrm{NSCSH}$ & 1.0 & 10 & 7 & 185 & 3.51 & 24.99 & 66.5 & 5 \\
\hline
\end{tabular}

respectively, are the absorbency of $\mathrm{RhB}$ solution at initial time and at time $t$ after UV irradiation at $554 \mathrm{~nm}$ [22].

Furthermore, some experiments were performed at solution temperatures of $20^{\circ} \mathrm{C}$ to determine the adsorption capacity of SCSH and NSCSH with different time intervals and lasted $150 \mathrm{~min}$. In addition, in order to determine the effect of adsorbent dosage, experiments were performed at adsorbent dosage of 40,60, 80, 100, and $120 \mathrm{mg}$. Similarly, the effect of $\mathrm{pH}$ was studied by using different buffer solutions for maintaining the $\mathrm{pH}$ at $2-10$. In order to determine adsorption isotherms parameters, experiments were carried out at solution temperatures of $20^{\circ} \mathrm{C}$ with different initial concentrations which varied from 5 to $25 \mathrm{mg} \mathrm{L}^{-1}$.

\section{Results and Discussion}

\subsection{Characterization of SCSH and NSCSH}

3.1.1. XRD Characterization. The XRD pattern of the SCSH and NSCSH are shown in Figure 1; peaks for $\mathrm{CaCO}_{3}$ decrease to the fact that during the hydrothermal reaction and desiccation process, SCSH consists of disordered calcium silicate hydrate gels with X-ray peaks at $0.303,0.292,0.3346,0.290$, and $0.1913 \mathrm{~nm}$. The peak of C-S-H gel at $0.303 \mathrm{~nm}$ is strong and sharp, but the peaks at $0.292,0.3346,0.290$, and $0.1913 \mathrm{~nm}$ are weak, indicating a poorly crystalline structure. Peaks with low intensity at 0.308 and $0.298 \mathrm{~nm}$ would indicate a tobermorite component but are weak, which is consistent with the main phase of SCSH being amorphous calcium silicate hydrate. However, the NSCSH sample is obviously different from SCSH. The intensities of amorphous C-S-H peaks are smaller and some new peaks appear, as is shown at 1.13, $0.308,0.298,0.280,0.184$, and $0.167 \mathrm{~nm}$, especially at $1.13 \mathrm{~nm}$ (corresponding to $7.8^{\circ}, 2 \theta$ ), which is the most characteristic peak of tobermorite as 002 orientation [34]. Moreover, peaks at $0.308,0.183,0.424$, and $0.282 \mathrm{~nm}$ (resp., corresponding to $28.9,49.5,20.9$, and $31.6^{\circ}$ ) represent the development of the $320,040,400$, and -321 reflections, indicating the formation of xonotlite. In particular, the sequence in which the Bragg peaks form during the crystallization reactions shows a clear pattern that the first peaks to form are at $\approx 3.0 \AA$, which is in the position as the xonotlite 320 peak. At the same time, a peak at $\approx 1.8 \AA$ forms, which is in the position as the xonotlite 040 peak. Hence, the xonotlite 320 and 040 peaks are more strong and sharp [9]. The results suggest that the main components of NSCSH are well-crystallized tobermorite and xonotlite, which can be attributed to the addition of $\mathrm{Ni}^{2+}$.

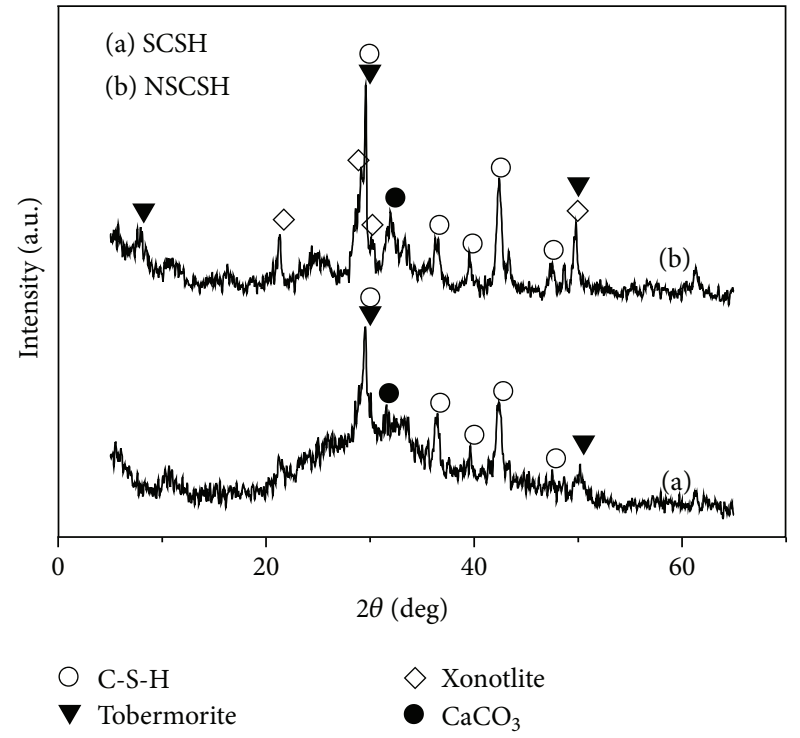

FIGURE 1: XRD patterns of (a) SCSH and (b) NSCSH.

3.1.2. SEM Characterization. SEM micrographs of SCSH and NSCSH are shown in Figure 2, which illustrate that the addition of $\mathrm{Ni}^{2+}$ significantly impacts the crystallinity and morphology of samples. The major product of SCSH is agglomerated with some flakey grains and fibrils accompanied by flocculation [35], which indicates C-S-H gel in Figure 2(a). It can be seen from Figure 2(b) that the microappearance of SCSH is structured by the flake-like hydrates (tobermorite) interlocked together with C-S-H [36]. However, the flakelike structure of tobermorite in Figure 2(b) was low and disordered compared with Figure 2(c) which presented a better crystalline tobermorite. In addition, a small amount of floccules are observed in the micrograph of NSCSH due to the residual C-S-H gels, which did not turn into tobermorite [37]. At the same time, the xonotlite crystals synthesized consist of tiny needle-like microfibers together with orbicular particles which was observed in Figure 2(d) [38]. Therefore, it can be inferred that part of tobermorite converted to xonotlite depending on the addition of $\mathrm{Ni}\left(\mathrm{NO}_{3}\right)_{2}$, and the fibrous xonotlites are closely associated with tobermorite plates. It is clear that the better crystalline tobermorite and xonotlite are the main components of NSCSH. As it is known, nickel existing in CSH gel is mainly in the form of nickel hydroxide [39]. With the addition of $\mathrm{Ni}^{2+}$, some of the $\mathrm{Ca}^{2+}$ ions presenting in the crystal lattice of NSCSH release to solution and exchange with $\mathrm{Ni}^{2+}$ ions [40]. Moreover, Komarneni et al. [41] have shown by TEM and EDS that $\mathrm{Ni}^{2+}$ could be 


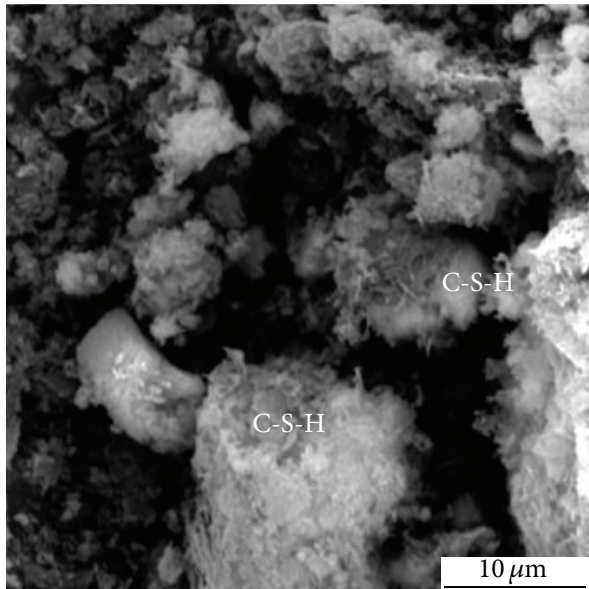

(a)

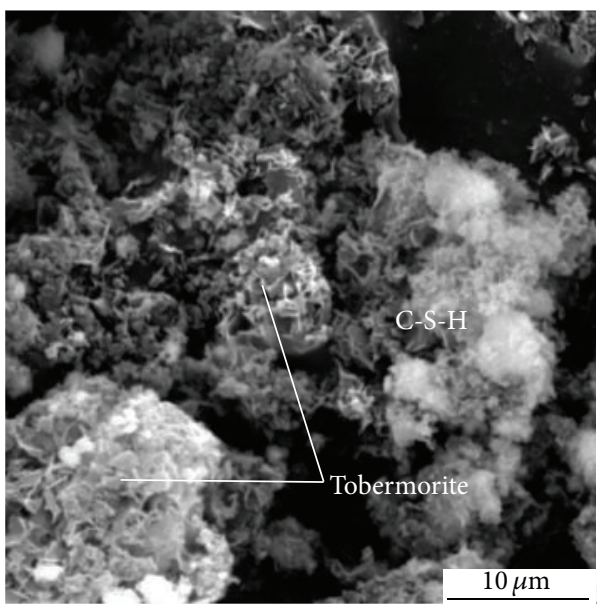

(c)

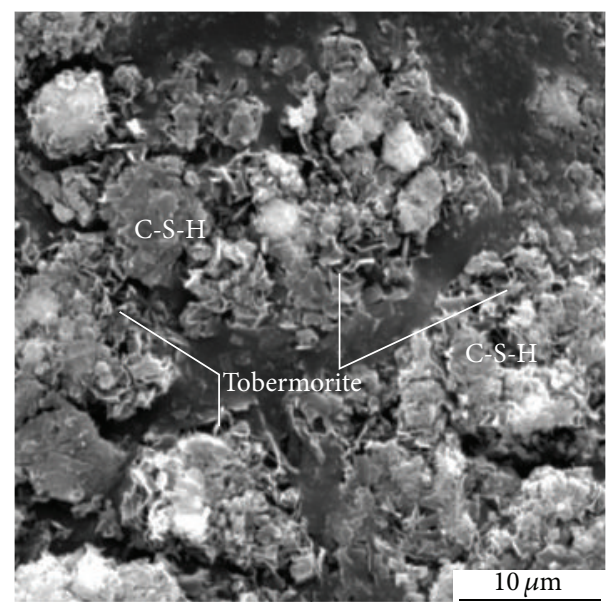

(b)

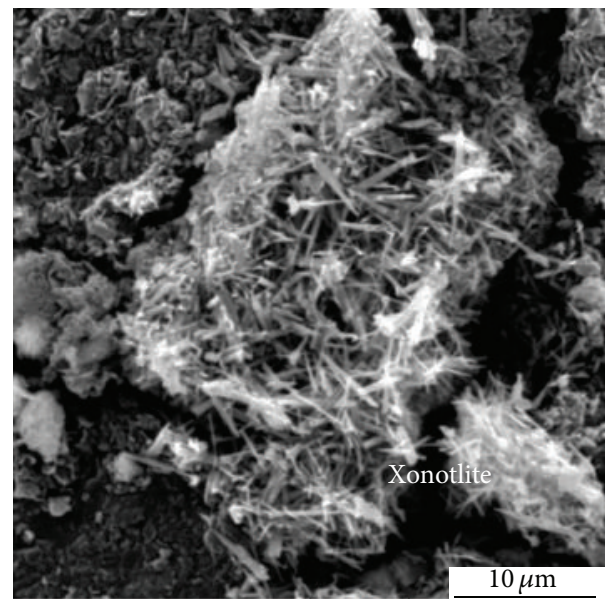

(d)

Figure 2: SEM micrographs of ((a), (b)) SCSH and ((c), (d)) NSCSH.

detected at the edge but not at the core upon reaction of CSHs with $\mathrm{Ni}^{2+}$, and $\mathrm{Ni}^{2+}$ in the solution of hydrating system is capable of binding some hydroxides. Therefore, some excess of calcium ions would be free in solution [35], and it indicates that the mechanism of reaction takes place from edge to core and the partial replacement of $\mathrm{Ca}^{2+}$ to $\mathrm{Ni}^{2+}$ will slow down the dissolution and subsequent further incorporation of calcium ions into the crystal structure of NSCSH, but calcium ions would be almost totally incorporated into the structure so that the reaction would be more complete and full. As a result, the dissolution of silicon component is promoted due to the adequate hydrothermal. Hence, the better crystalline tobermorite and xonotlite can be obtained with better pore structure and adsorption capacities.

3.1.3. $\mathrm{N}_{2}$ Adsorption/Desorption. BET surface area, total pore volume, and pore diameter of the samples were measured. The data are summarized in Table 4 and nitrogen adsorptiondesorption isotherms and pore size distribution curves of SCSH and NSCSH are shown in Figure 3. Based on the pore diameter, samples are characterized as mesoporous material
TABLE 4: The structure characteristics of samples.

\begin{tabular}{lccc}
\hline Sample & $\begin{array}{c}\text { Surface area } \\
\left(\mathrm{m}^{2} \cdot \mathrm{g}^{-1}\right)\end{array}$ & $\begin{array}{c}\text { Pore volume } \\
\left(\mathrm{cm}^{3} \cdot \mathrm{g}^{-1}\right)\end{array}$ & $\begin{array}{c}\text { Pore diameter } \\
(\mathrm{nm})\end{array}$ \\
\hline SCSH & 72.47 & 0.27 & 15.85 \\
NSCSH & 77.88 & 0.25 & 13.45 \\
\hline
\end{tabular}

$(2 \mathrm{~nm}<$ pore diameter $<50 \mathrm{~nm})$. As is seen from Figure 3, the obtained $\mathrm{N}_{2}$ adsorption isotherms of samples exhibit Type II behaviors (according to IUPAC classification), characteristics of major mesoporous, and a few microporous adsorbents. Type II isotherm represents unrestricted monolayermultilayer adsorption. Meanwhile, Point B of curves always exist in the area of low relative pressure, indicating the stage at which monolayer coverage is complete and multilayer adsorption is about to begin [42]. Besides, $\mathrm{N}_{2}$ absorbance of mesoporous SCSH does not have any limits in the area of high relative pressure, which fits to the $\mathrm{H} 3$ hysteresis loops, and it implies that the plate-like particles give rise to slitshaped pores. However, the hysteresis type of NSCSH is H1, which is often associated with porous materials that consist of 


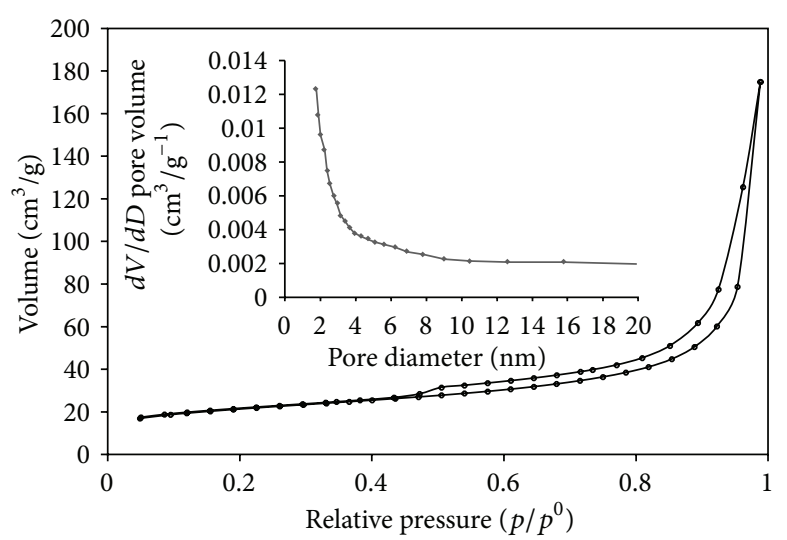

(a)

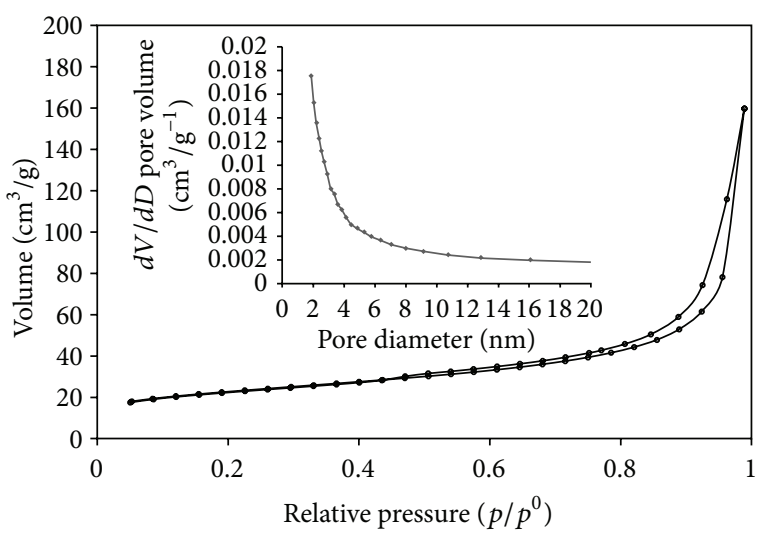

(b)

FIGURE 3: $\mathrm{N}_{2}$ adsorption-desorption isotherms and pore size distribution curves of (a) SCSH and (b) NSCSH.

agglomerates or compacts of approximately uniform spheres in fairly regular array, hence having narrow distributions of pore size [42]. From Table 4, the BET surface area of NSCSH increases compared with SCSH, but the average pore volume and average pore diameters both decrease, indicating that the addition of $\mathrm{Ni}^{2+}$ is beneficial to prepare the sample, having more narrow pores instead of slit-shaped pores, indicating a better adsorption capacity of NSCSH.

\subsection{Adsorption Studies}

3.2.1. Effects of Reaction Time. The effects of reaction time on the removal of RhB for SCSH and NSCSH are shown in Figure 4. It can be seen that the adsorption of RhB for both SCSH and NSCSH occurs from the beginning of the experiment, and, as time progresses, the adsorption does not drastically increase. Furthermore, the adsorbent concentrations used in this study are $100 \mathrm{mg} \mathrm{L}^{-1}$ for both samples. The maximum adsorption takes place at around 30-50 min for both samples. After this time, the adsorption rate is slow, leading to a single, smooth, and continuous saturation curve [43]. With the addition of $\mathrm{Ni}^{2+}$, the maximum removal rate of $\mathrm{RhB}$ correspondingly increases from $52.4 \%$ to $88.2 \%$. The major product of NSCSH is flake-like structure of tobermorite and tiny needle-like microfibers together with orbicular particles structure of xonotlite which is attributed to a larger specific surface area of NSCSH; hence, the adsorption performance is more stable and efficient. As the adsorption efficiency of NSCSH is much better than that of SCSH, the following discussion will be focused on the adsorption capacity of NSCSH.

3.2.2. Effects of Adsorbent Dosage. Adsorbent dosage is an important factor in the adsorption process, which significantly influences the removal effect of adsorbate. The effect of different adsorbent dosages on the uptake of RhB by NSCSH is shown in Figure 5 for dosages of $40-120 \mathrm{mg}$ in a volume of $100 \mathrm{~mL}$ at the initial dye concentration, $100 \mathrm{mg} \mathrm{L}^{-1}$, and all

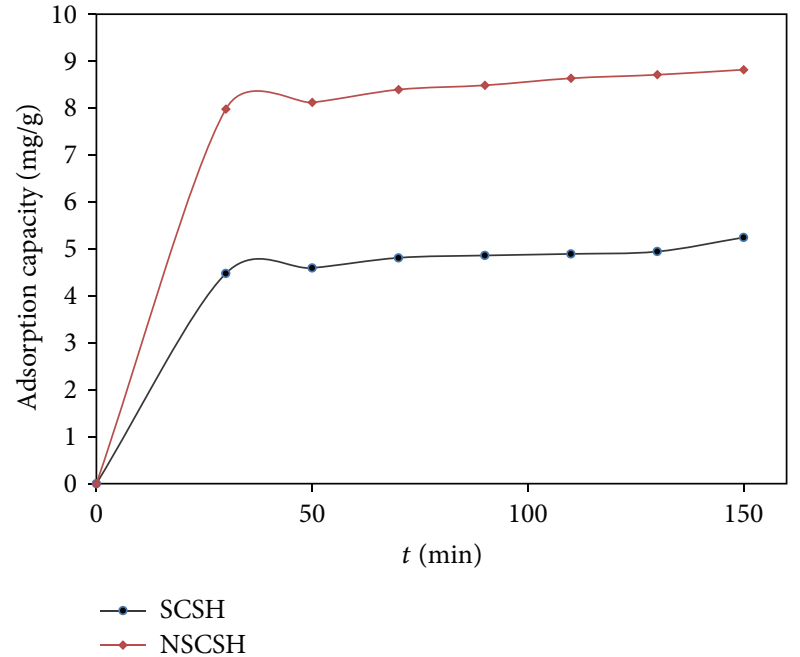

FIGURE 4: Effect of time on the adsorption of RhB onto SCSH and $\mathrm{NSCSH}$

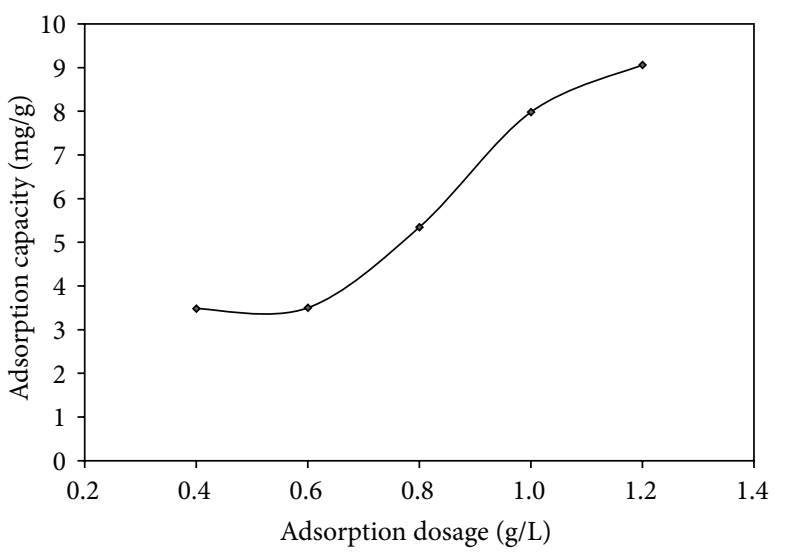

FIGURE 5: Effect of adsorbent dosage on the adsorption of RhB onto NSCSH. 


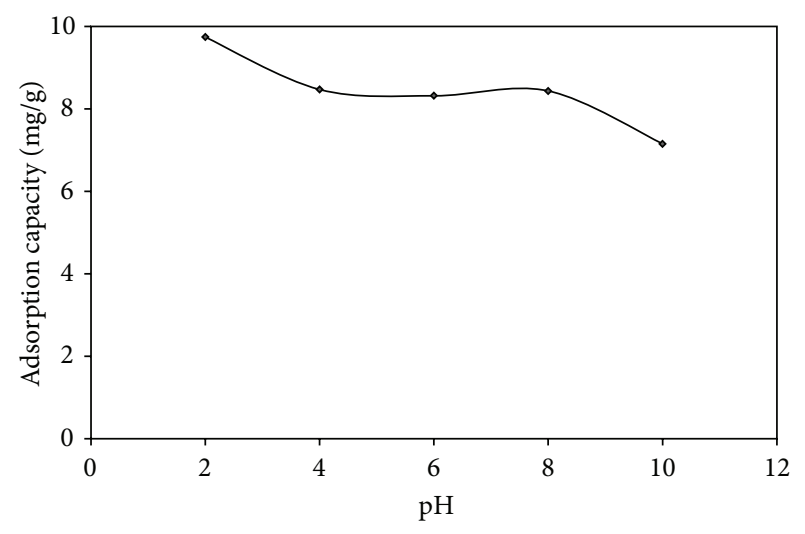

FIGURE 6: Effect of $\mathrm{pH}$ on the adsorption of RhB onto NSCSH.

experiments are at the same temperature and at optimum $\mathrm{pH}$ constant for $30 \mathrm{~min}$ time intervals. As the dosage of adsorbent increases, the removal rate of $\mathrm{RhB}$ correspondingly increases from $34.8 \%$ to $90.6 \%$. It is attributed to the greater surface area and availability of more active sites for adsorption while the increasing of adsorbent dosage, which lead to the increase of the removal rate of dye from the solution finally [44]. However, when the adsorbent dosage is $100 \mathrm{mg} \mathrm{L}^{-1}$, more than $80 \% \mathrm{RhB}$ has been removed from the solution. Thus, considering the efficiency of experiments, the optimum dosage of adsorbent is selected at $100 \mathrm{mg} / \mathrm{L}$ for the following experiments.

3.2.3. Effects of $p H$. The initial $\mathrm{pH}$ of dye solution is an important parameter that affects the adsorption property of an adsorbent. In particular, the $\mathrm{pH}$ of the solution changes due to (1) surface charges of the adsorbent; (2) the degree of ionization of the adsorptive molecule; (3) the dissociation extent of functional groups on the active sites of the adsorbent [45]. To study the effects of the initial solution $\mathrm{pH}$ on $\mathrm{RhB}$ adsorption of the synthesized NSCSH, different initial $\mathrm{pH}$ between 2.0 and 10.0 was used. Figure 6 shows that the adsorption capacity of $\mathrm{RhB}$ decreases with the increase of the initial $\mathrm{pH}$, which reaches a plateau value with $\mathrm{pH}$ from 3.0 to 8.0 , and then decreases with $\mathrm{pH}$ above 8.0. However, the removal process of $\mathrm{RhB}$ for NSCSH is very complex and is related to the dissociation properties of the solution and the nature of the substrate surface. Thus, for a value of 3.0 for the $\mathrm{RhB}$ pKa, the surface charge value is positive at $\mathrm{pH}<3.0$ while the carboxyl group is unionized [46]. The electrostatic attraction between cationic RhB and negatively charged NSCSH leads to the increase of adsorption. When $\mathrm{pH}$ value is above 3.0 , the carboxyl group starts to become ionized, which conduces to the competition between $\mathrm{COO}^{-}$ and hydroxyl group of CSHs, leading to the decrease of $\mathrm{RhB}$ adsorption onto NSCSH.

3.2.4. Adsorption Isotherms. The equilibrium adsorption isotherm is important in reflecting the interactive behavior between adsorbate and adsorbent. Therefore, two main

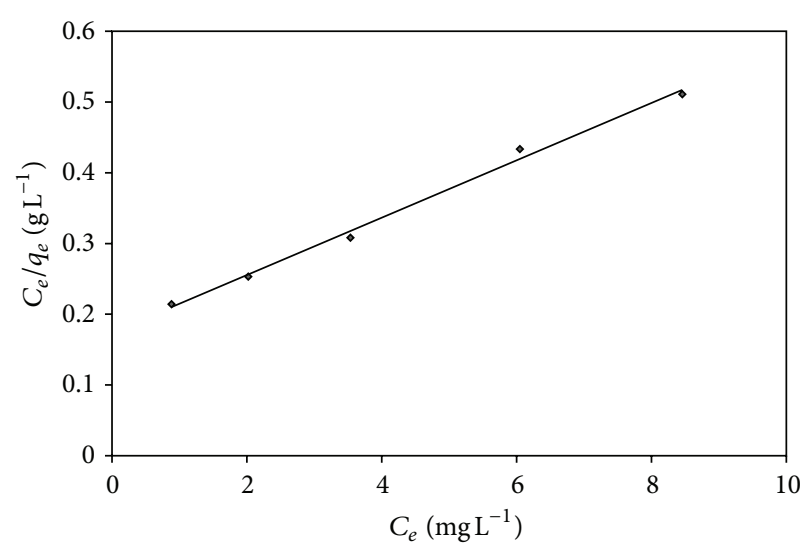

FIGURE 7: Langmuir adsorption isotherm for RhB onto NSCSH.

equations of adsorption isotherm are analyzed, namely, the Langmuir [47] and Freundlich isotherm [48].

The Langmuir isotherm theory assumes a monolayer coverage of adsorbate over a homogenous adsorbent surface; it is represented by (A.2), where $C_{e}$ is the concentration of dye solution at equilibrium $\left(\mathrm{mg} \mathrm{L}^{-1}\right), q_{e}$ is amount of dye absorbed at equilibrium $\left(\mathrm{mg} \mathrm{g}^{-1}\right), Q_{0}$ is the maximum absorbance ( $\mathrm{mg} \mathrm{g}^{-1}$ ), and $b$ is the Langmuir constant related to energy of adsorption $\left(\mathrm{L} \mathrm{mg}^{-1}\right)$.

The plots of $C_{e} / q_{e}$ versus $C_{e}$ for $\mathrm{RhB}$ with concentrations of $5,10,15,20$, and $25 \mathrm{mg} \mathrm{L}^{-1}$ are shown in Figure 7. Values of $Q_{0}$ and $b$ are obtained from the slope and intercept of plot of $C_{e} / q_{e}$ versus $C_{e}$ and are given in Table 5 . It can be seen that the correlation coefficients $\left(R^{2}\right)$ are close to unity, indicating the monolayer adsorption of $\mathrm{RhB}$ on the outer surface of adsorbent.

The essential characteristics of the Langmuir isotherm can be expressed in terms of a dimensionless constant separation factor $R_{L}$ called equilibrium parameter which is given by (A.3), where values of $b$ and $C_{0}$ are obtained from the Langmuir isotherm.

The value of $R_{L}$ indicates that the type of the isotherm is either to unfavourable $\left(R_{L}>1\right)$, linear $\left(R_{L}=1\right)$, favorable $\left(0<R_{L}<1\right)$, or irreversible $\left(R_{L}=0\right)$ [43]. It is clear that the values of $R_{L}$ are 0.148 (Table 5), indicating a favorable adsorption in this case. The adsorption isotherm is also applied to the Freundlich model. This model is based on an adsorbent surface which has a heterogeneous energy distribution of active sites. Theoretically, the Freundlich model is suitable for use with heterogeneous surfaces and, with this expression, an infinite amount of adsorption can occur [49]. The Freundlich isotherm is described by (A.4), where $q_{e}$ is the dye concentration for a solid at equilibrium $\left(\mathrm{mg} \mathrm{g}^{-1}\right), C_{e}$ is the dye concentration in solution at equilibrium $\left(\mathrm{mg} \mathrm{L}^{-1}\right), K_{f}$ is the measure of the adsorption capacity, and $n$ is a constant related to adsorption intensity [50].

The plot of $\log q_{e}$ versus $\log C_{e}$ for $\mathrm{RhB}$ is shown in Figure 8. The values of $n$ and $K_{f}$ are calculated from slope and intercept of this plot and $t$ values are given in Table 5. It shows that the values of $\mathrm{n}$ fall between 1 and 10 , indicating 
TABLE 5: Isotherm parameters for RhB adsorption onto NSCSH.

\begin{tabular}{lcccccr}
\hline Sample & \multicolumn{2}{c}{ Langmuir } & \multicolumn{2}{c}{ Freundlich } \\
$\begin{array}{c}Q_{0} \\
\left(\mathrm{mg} \mathrm{g}^{-1}\right)\end{array}$ & $\begin{array}{c}b \\
\left(\mathrm{~L} \mathrm{mg}^{-1}\right)\end{array}$ & $R_{L}$ & $R^{2}$ & $K_{f}$ \\
$\left(\mathrm{mgg}^{-1}\right)$ & $R^{2}$ \\
\hline NSCSH & 25 & 0.23 & 0.148 & 0.994 & 4.82 & 1.65 \\
\hline
\end{tabular}

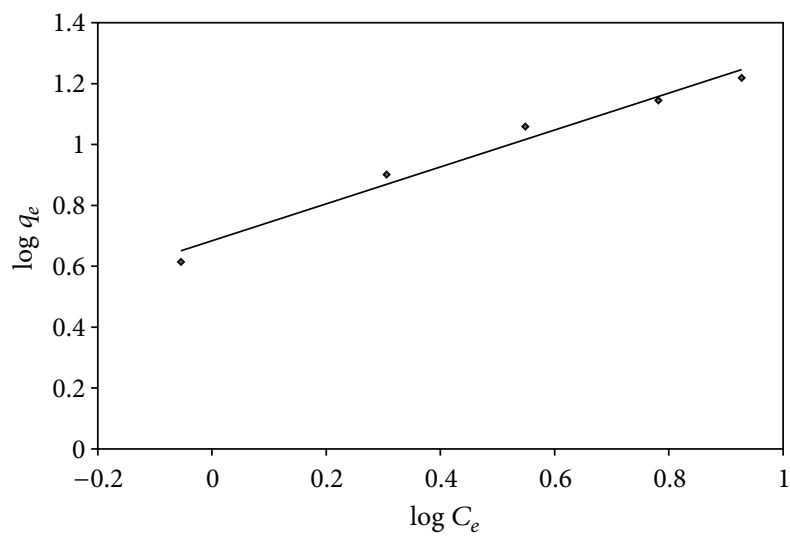

FIGURE 8: Freundlich adsorption isotherm for RhB onto NSCSH.

a beneficial adsorption. However, the dimensionless constant $\left(R_{L}=0.148\right)$ falls within the favorable limit in adsorbent. Meanwhile, compared with the values of $R^{2}$, it is noted that the Freundlich model is slightly smaller than the Langmuir model indicating that the Langmuir model is the better fit model for the adsorption of RhB onto NSCSH.

\section{Conclusion}

This paper describes the characteristics of Ni-doped calcium silicate hydrate based on steel slag and investigated the performance of NSCSH for the adsorption of $\mathrm{RhB}$ from aqueous solution. The SEM and XRD results indicate that the addition of $\mathrm{Ni}\left(\mathrm{NO}_{3}\right)_{2}$ promoted the formation of better crystalline tobermorite and xonotlite, resulting in a higher adsorption of RhB. The following conclusions can be drawn.

(1) Hydrothermal synthesized SCSH and NSCSH products both absorb RhB from solution, but NSCSH was much more effective. This is due to better pore structure and lager surface area of flake-like structure of tobermorite and tiny needle-like microfibers together with orbicular particles structure of xonotlite onto NSCSH.

(2) The adsorption capacity of RhB onto NSCSH was almost constant when $\mathrm{pH}$ value was in the range of 3.0 to 8.0, but it decreased when $\mathrm{pH}$ value is above 8.0.

(3) The experimental data of NSCSH was treated with the Langmuir and Freundlich isotherm equations. The analysis of the obtained parameters and correlation coefficients for both models showed that the adsorption behavior of $\mathrm{RhB}$ onto NSCSH is slightly better explained using a Langmuir model than a Freundlich model, which showed that in general the type of the isotherm was favorable $\left(0<R_{L}<1\right)$.
(4) Steel slag, a common industrial waste material, could be a useful, simple, and inexpensive source of material for producing CSH samples which could have great potential for the removal of dye from aqueous solutions.

\section{Appendix}

Formulae and equations are as follows:

$$
\begin{aligned}
\eta & =\left[\frac{A_{C 0}-A_{C t}}{A_{C 0}}\right] \times 100, \\
\frac{C_{e}}{q_{e}} & =\frac{C_{e}}{Q_{0}}+\frac{1}{b Q_{0}}, \\
R_{L} & =\frac{1}{1+b C_{0}}, \\
\log q_{e} & =\frac{1}{n} \log C_{e}+\log K_{f} .
\end{aligned}
$$

\section{Conflict of Interests}

The authors declare that there is no conflict of interests regarding the publication of this paper.

\section{Acknowledgment}

The study is supported by the National Natural Science Foundation of China (51402029).

\section{References}

[1] G. L. Kalousek, "Crystal chemistry of hydrous calcium silicates. I. Substitution of aluminum in lattice of tobermorite," Journal of the American Ceramic Society, vol. 40, no. 3, pp. 74-80, 1957.

[2] S. Komarneni and D. M. Roy, "New tobermorite cation exchangers," Journal of Materials Science, vol. 20, no. 8, pp. 2930-2936, 1985.

[3] C. Henmi and I. Kusachi, "Clinotobermorite, $\mathrm{Ca}_{5} \mathrm{Si}_{6}(\mathrm{O}, \mathrm{OH})_{18} \cdot 5 \mathrm{H}_{2} \mathrm{O}$ a new mineral from Fuka, Okayama Prefecture, Japan," Mineralogical Magazine, vol. 56, no. 384, pp. 353-358, 1992.

[4] A. Livingstone, "Reyerite, tobermorite, calcian analcime and bytownite from amygdales in a Skye basalt," Mineralogical Magazine, vol. 52, no. 368, pp. 711-713, 1988.

[5] X. C. Chen, H. N. Kong, D. Y. Wu, X. Z. Wang, and Y. Y. Lin, "Phosphate removal and recovery through crystallization of hydroxyapatite using xonotlite as seed crystal," Journal of Environmental Sciences, vol. 21, no. 5, pp. 575-580, 2009.

[6] C. Hejny and T. Armbruster, "Polytypism in xonotlite $\mathrm{Ca}_{6} \mathrm{Si}_{6} \mathrm{O}_{17}(\mathrm{OH})_{2}$," Zeitschrift fur Kristallographie, vol. 216, no. 7, pp. 396-408, 2001. 
[7] S. Merlino, E. Bonaccorsi, and T. Armbruster, "The real structure of tobermorite 11 angstrom: normal and anomalous forms, OD character and polytypic modifications," European Journal of Mineralogy, vol. 13, no. 3, pp. 577-590, 2001.

[8] S. A. Hamid, "The crystal structure of the $11 \ddot{A}$ natural tobermorite $\mathrm{Ca}_{2.25}\left[\mathrm{Si}_{3} \mathrm{O}_{7.5}(\mathrm{OH})_{1.5}\right] \cdot 1 \mathrm{H}_{2} \mathrm{O}$," Zeitschrift für Kristallographie, vol. 154, no. 1-4, pp. 189-198, 1981.

[9] S. Shaw, S. M. Clark, and C. M. B. Henderson, "Hydrothermal formation of the calcium silicate hydrates, tobermorite $\left(\mathrm{Ca}_{5} \mathrm{Si}_{6} \mathrm{O}_{16}(\mathrm{OH})_{2} \cdot 4 \mathrm{H}_{2} \mathrm{O}\right)$ and xonotlite $\left(\mathrm{Ca}_{6} \mathrm{Si}_{6} \mathrm{O}_{17}(\mathrm{OH})_{2}\right)$ : an in situ synchrotron study," Chemical Geology, vol. 167, no. 1-2, pp. 129-140, 2000.

[10] K. S. Mamedov and N. V. Belov, "Kristallicheskaya Struktura Ksonotlita," Doklady Akademii Nauk SSSR, vol. 104, no. 4, pp. 615-618, 1955.

[11] M.-P. Pomiès, N. Lequeux, and P. Boch, "Speciation of cadmium in cement: part I. Cd $\mathrm{Cd}^{2+}$ uptake by C-S-H," Cement and Concrete Research, vol. 31, no. 4, pp. 563-569, 2001.

[12] T. Tsutsumi, S. Nishimoto, Y. Kameshima, and M. Miyake, "Hydrothermal preparation of tobermorite from blast furnace slag for $\mathrm{Cs}^{+}$and $\mathrm{Sr}^{2+}$ sorption," Journal of Hazardous Materials, vol. 266, pp. 174-181, 2014.

[13] N. J. Coleman, "Interactions of Cd(II) with waste-derived 11 angstrom tobermorites," Separation and Purification Technology, vol. 48, no. 1, pp. 62-70, 2006.

[14] P. Mandaliev, E. Wieland, R. Dähn, J. Tits, S. V. Churakov, and O. Zaharko, "Mechanisms of Nd(III) uptake by $11 \AA \AA$ tobermorite and xonotlite," Applied Geochemistry, vol. 25, no. 6, pp. 763-777, 2010.

[15] P. Mandaliev, T. Stumpf, J. Tits, R. Dähn, C. Walther, and E. Wieland, "Uptake of Eu(III) by 11 angstrom tobermorite and xonotlite: a TRLFS and EXAFS study," Geochimica et Cosmochimica Acta, vol. 75, no. 8, pp. 2017-2029, 2011.

[16] O. P. Shrivastava and T. Verma, " $\mathrm{Sr}^{2+}$ sorption and leach rate studies on synthetic calcium silicate hydroxy hydrate," Advanced Cement Based Materials, vol. 2, no. 3, pp. 119-124, 1995.

[17] H. Katsumata, S. Kaneco, R. Matsuno et al., "Removal of organic polyelectrolytes and their metal complexes by adsorption onto xonotlite," Chemosphere, vol. 52, no. 5, pp. 909-915, 2003.

[18] S. Wang, X. Peng, L. Tang, L. Zeng, and C. Lan, "Influence of inorganic admixtures on the $11 \AA$-tobermorite formation prepared from steel slags: XRD and FTIR analysis," Construction and Building Materials, vol. 60, pp. 42-47, 2014.

[19] H. Motz and J. Geiseler, "Products of steel slags an opportunity to save natural resources," Waste Management, vol. 21, no. 3, pp. 285-293, 2001.

[20] J. Xiong, Z. He, Q. Mahmood, D. Liu, X. Yang, and E. Islam, "Phosphate removal from solution using steel slag through magnetic separation," Journal of Hazardous Materials, vol. 152, no. 1, pp. 211-215, 2008.

[21] V. K. Jha, Y. Kameshima, A. Nakajima, and K. Okada, "Utilization of steel-making slag for the uptake of ammonium and phosphate ions from aqueous solution," Journal of Hazardous Materials, vol. 156, no. 1-3, pp. 156-162, 2008.

[22] Y. J. Zhang, L. C. Liu, Y. Xu, Y. C. Wang, and D. L. Xu, "A new alkali-activated steel slag-based cementitious material for photocatalytic degradation of organic pollutant from waste water," Journal of Hazardous Materials, vol. 209-210, pp. 146150, 2012.
[23] A. Bhatnagar and A. K. Jain, "A comparative adsorption study with different industrial wastes as adsorbents for the removal of cationic dyes from water," Journal of Colloid and Interface Science, vol. 281, no. 1, pp. 49-55, 2005.

[24] V. K. Jha, Y. Kameshima, A. Nakajima, and K. Okada, "Hazardous ions uptake behavior of thermally activated steelmaking slag," Journal of Hazardous Materials, vol. 114, no. 1-3, pp. 139-144, 2004.

[25] S. Asaoka, H. Okamura, R. Morisawa et al., "Removal of hydrogen sulfide using carbonated steel slag," Chemical Engineering Journal, vol. 228, pp. 843-849, 2013.

[26] S. D. Richardson, C. S. Willson, and K. A. Rusch, "Use of rhodamine water tracer in the marshland upwelling system," Ground Water, vol. 42, no. 5, pp. 678-688, 2004.

[27] J. Rochat, P. Demenge, and J. C. Rerat, "Toxicologic study of a fluorescent tracer: rhodamine B," Toxicological European Research, vol. 1, no. 1, pp. 23-26, 1978.

[28] P. V. Messina and P. C. Schulz, "Adsorption of reactive dyes on titania-silica mesoporous materials," Journal of Colloid and Interface Science, vol. 299, no. 1, pp. 305-320, 2006.

[29] S. Wang, H. Li, and L. Xu, "Application of zeolite MCM-22 for basic dye removal from wastewater," Journal of Colloid and Interface Science, vol. 295, no. 1, pp. 71-78, 2006.

[30] V. K. Gupta, Suhas, I. Ali, and V. K. Saini, "Removal of rhodamine B, fast green, and methylene blue from wastewater using red mud, an aluminum industry waste," Industrial \& Engineering Chemistry Research, vol. 43, no. 7, pp. 1740-1747, 2004.

[31] S. B. Wang and Z. H. Zhu, "Characterisation and environmental application of an Australian natural zeolite for basic dye removal from aqueous solution," Journal of Hazardous Materials, vol. 136, no. 3, pp. 946-952, 2006.

[32] S. B. Wang, M. Soudi, L. Li, and Z. H. Zhu, "Coal ash conversion into effective adsorbents for removal of heavy metals and dyes from wastewater," Journal of Hazardous Materials, vol. 133, no. 1-3, pp. 243-251, 2006.

[33] G. Annadurai, R.-S. Juang, and D.-J. Lee, "Use of cellulose-based wastes for adsorption of dyes from aqueous solutions," Journal of Hazardous Materials, vol. 92, no. 3, pp. 263-274, 2002.

[34] K. Matsui, J. Kikuma, M. Tsunashima et al., "In situ timeresolved X-ray diffraction of tobermorite formation in autoclaved aerated concrete: influence of silica source reactivity and $\mathrm{Al}$ addition," Cement and Concrete Research, vol. 41, no. 5, pp. 510-519, 2011.

[35] W. Nocuò-Wczelik, "Effect of $\mathrm{Na}$ and $\mathrm{Al}$ on the phase composition and morphology of autoclaved calcium silicate hydrates," Cement and Concrete Research, vol. 29, no. 11, pp. 1759-1767, 1999.

[36] L. Hou, J. H. Li, and L. X. Tong, "Preparation and characterization of calcium silicate slag based lightweight wall materials," in Proceedings of the 7th China International Conference on HighPerformance Ceramics, vol. 512-515, pp. 110-114, 2012.

[37] L. Zeng, L. Yang, S. Wang, and K. Yang, "Synthesis and characterization of different crystalline calcium silicate hydrate: application for the removal of aflatoxin b1 from aqueous solution," Journal of Nanomaterials, vol. 2014, Article ID 431925, 10 pages, 2014.

[38] J. X. Cao, F. Liu, Q. Lin, and Y. Zhang, "Hydrothermal synthesis of xonotlite from carbide slag," Progress in Natural Science, vol. 18, no. 9, pp. 1147-1154, 2008. 
[39] N. Gineys, G. Aouad, and D. Damidot, "Managing trace elements in Portland cement-part I: interactions between cement paste and heavy metals added during mixing as soluble salts," Cement and Concrete Composites, vol. 32, no. 8, pp. 563-570, 2010.

[40] S. A. El-Korashy, "Synthetic crystalline calcium silicate hydrate (I): cation exchange and caesium selectivity," Monatshefte für Chemie, vol. 133, no. 3, pp. 333-343, 2002.

[41] S. Komarneni, E. Breval, D. M. Roy, and R. Roy, "Reactions of some calcium silicates with metal cations," Cement and Concrete Research, vol. 18, no. 2, pp. 204-220, 1988.

[42] K. S. W. Sing, "Reporting physisorption data for gas/solid systems with special reference to the determination of surface area and porosity (Provisional)," Pure and Applied Chemistry, vol. 54, no. 11, pp. 2201-2218, 1982.

[43] P. Baskaralingam, M. Pulikesi, D. Elango, V. Ramamurthi, and S. Sivanesan, "Adsorption of acid dye onto organobentonite," Journal of Hazardous Materials, vol. 128, no. 2-3, pp. 138-144, 2006.

[44] K. Rida, S. Bouraoui, and S. Hadnine, "Adsorption of methylene blue from aqueous solution by kaolin and zeolite," Applied Clay Science, vol. 83-84, pp. 99-105, 2013.

[45] B. K. Nandi, A. Goswami, and M. K. Purkait, "Removal of cationic dyes from aqueous solutions by kaolin: kinetic and equilibrium studies," Applied Clay Science, vol. 42, no. 3-4, pp. 583-590, 2009.

[46] A. D. Robison, D. Huang, H. Jung, and P. S. Cremer, "Fluorescence modulation sensing of positively and negatively charged proteins on lipid bilayers," Biointerphases, vol. 8, no. 1, pp. 1-9, 2013.

[47] I. Langmuir, "The constitution and fundamental properties of solids and liquids. Part I. Solids," The Journal of the American Chemical Society, vol. 38, no. 2, pp. 2221-2295, 1916.

[48] H. Freundlich, "Concerning adsorption in solutions," Zeitschrift fur Physikalische Chemie-Stochiometrie und Verwandtschaftslehre, vol. 57, no. 4, pp. 385-470, 1906.

[49] B. Ismail, S. T. Hussain, and S. Akram, "Adsorption of methylene blue onto spinel magnesium aluminate nanoparticles: adsorption isotherms, kinetic and thermodynamic studies," Chemical Engineering Journal, vol. 219, pp. 395-402, 2013.

[50] L. Zeng, S. P. Wang, X. Q. Peng, J. Q. Geng, C. Y. Chen, and M. $\mathrm{Li}$, "Al-Fe PILC preparation, characterization and its potential adsorption capacity for aflatoxin B1," Applied Clay Science, vol. 83-84, pp. 231-237, 2013. 

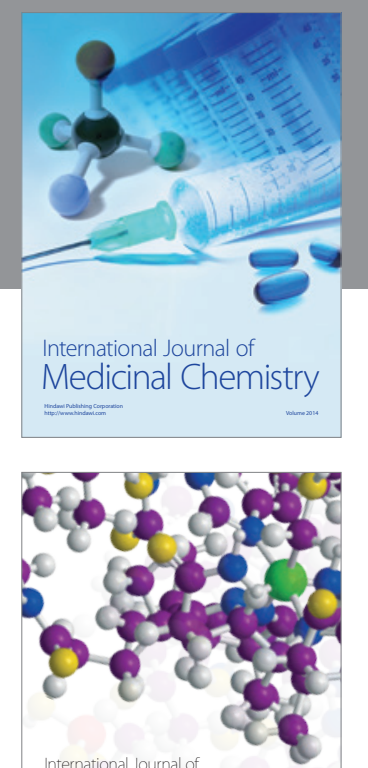

\section{Carbohydrate} Chemistry

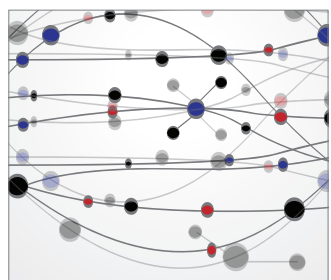

The Scientific World Journal
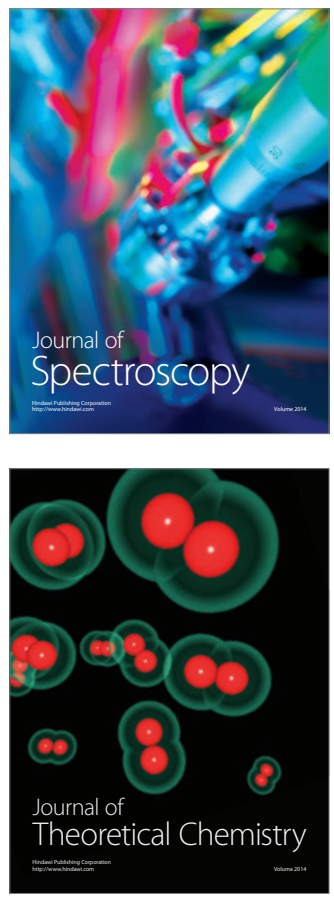
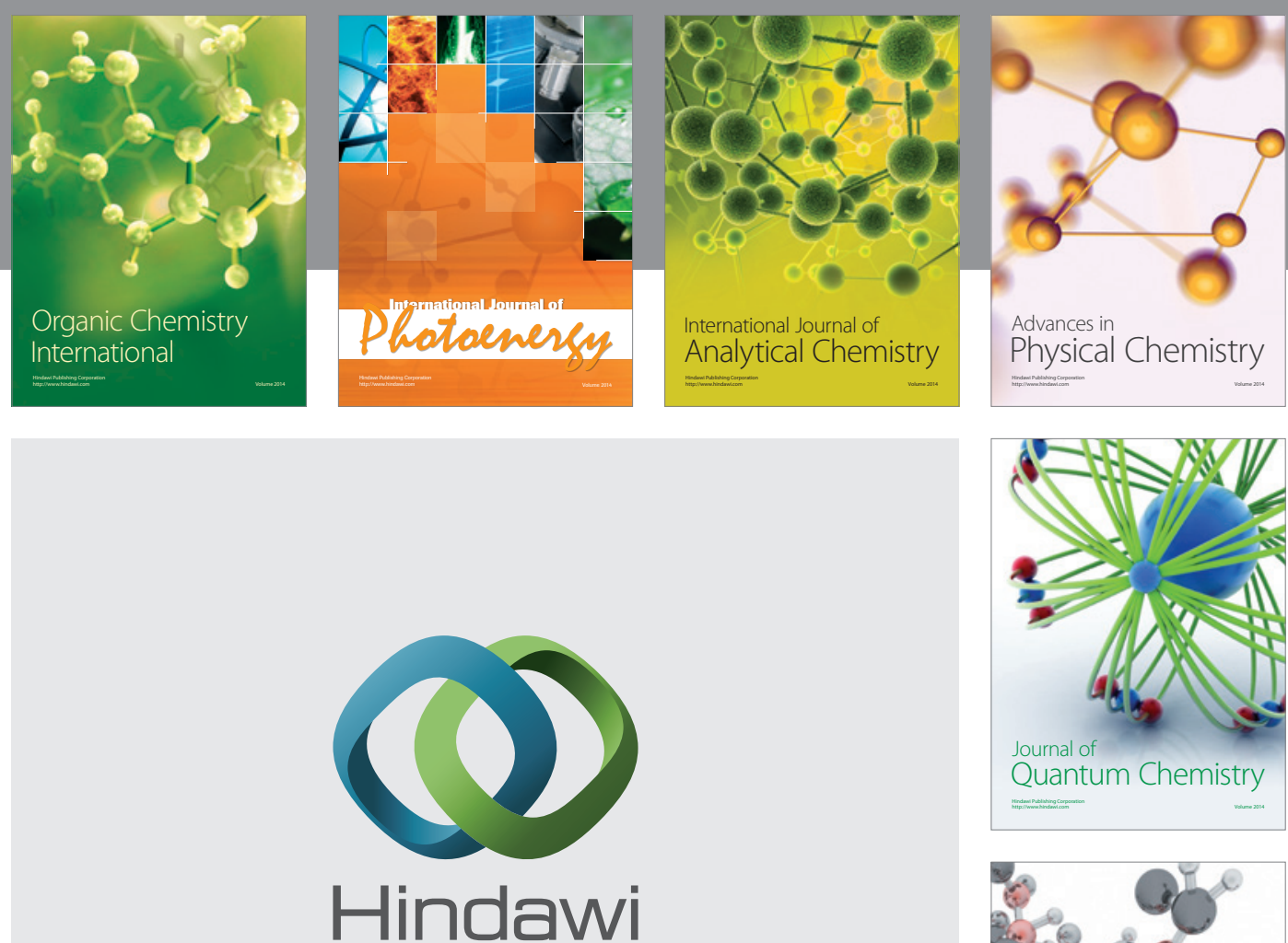

Submit your manuscripts at

http://www.hindawi.com

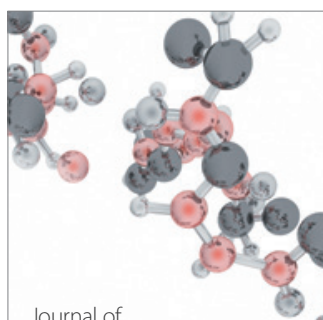

Analytical Methods

in Chemistry

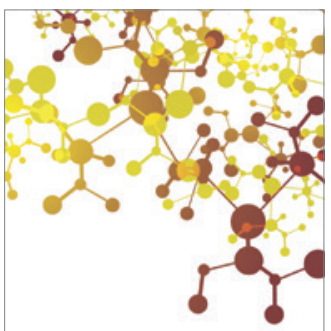

Journal of

Applied Chemistry

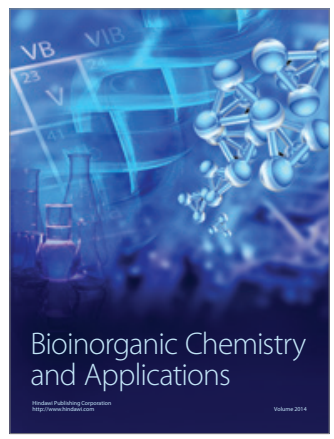

Inorganic Chemistry
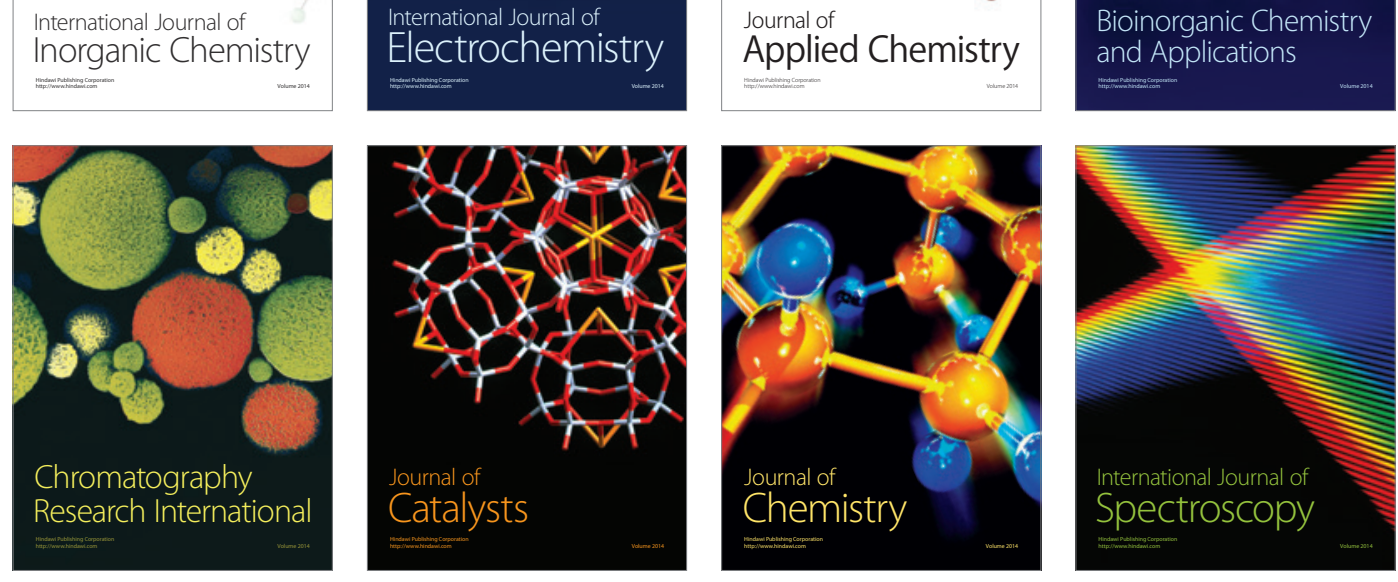